\title{
Repositioning Secondary School Administration for Quality Assurance in Ekiti State, Nigeria
}

\author{
Babatope Kolade Oyewole ${ }^{1}$ \\ ${ }^{1}$ Department of Educational Foundations \& Management, Faculty of Education, Ekiti State University, Nigeria \\ Correspondence: Babatope Kolade Oyewole, Department of Educational Foundations \& Management, Faculty \\ of Education, Ekiti State University, Ado- Ekiti, Ekiti State, Nigeria. E-mail: Oyewole.tope@yahoo.com
}

\author{
Received: October 28, 2012 Accepted: March 25, 2013 Online Published: July 4, 2013 \\ doi:10.5539/jms.v3n3p173 URL: http://dx.doi.org/10.5539/jms.v3n3p173
}

\begin{abstract}
This paper discusses the challenges and prospects of repositioning secondary school administration for quality assurance in Ekiti State, Nigeria. In recent time, there had been a radical transformation of the education sector in Ekiti State part of which included the restructuring of the secondary school system. The senior and junior secondary schools were merged together to become a single school under the administration of a school principal. This paper examines the strategies used in repositioning secondary school administration for quality assurance by the state government. It highlights the challenges of repositioning the school administration based on the public outcry and the reactions of the school principals towards this new development. It x- rays the prospects of repositioning secondary school administration for quality assurance in Ekiti State to include high competency of secondary school administrators, removal of dichotomy between senior and junior secondary schools, unity and team work spirit among teachers, centralization of school policies, improved school infrastructures and facilities, and effective supervision of school personnel. The paper recommended among others that the Teaching Service Commission in Ekiti State should always consider performance, competency and years of experience in the appointment of secondary school principals.
\end{abstract}

Keywords: repositioning, quality assurance, school principal, senior school, junior school, performance

\section{Introduction}

Education is the largest industry in Ekiti State. Indeed, it is the most expensive sector of the economy as the state government strives hard to ensure quality in the delivery of educational programmes to her citizenry at all levels of educational system in Ekiti State purposely to justify the acronym which refers to Ekiti State as "Fountain of Knowledge and Land of Honour".

The radical transformation to revamp the ailing educational system in Ekiti State especially at the secondary school level is quite laudable and remarkable. There is a clear departure from the old practice of having two principals in a school (senior secondary school principal and junior secondary school principal) with the merger of the two schools to become one under the administration of a single principal.

The poor performance of secondary school students especially in public examinations in recent times has been very worrisome to all the stake holders in the education sector. Despite the huge investment by the state government on secondary school education in Ekiti State, little had been achieved as regards good academic performance of students in West African Examinations Council (WAEC) and National Examination Council (NECO) conducted examinations at Senior School Certificate Examination (SSCE) results. All attention has been focused on the school principals as they manage the affairs of the school system. Wekessa (1993) opined that to improve students' academic performance, principals are required to improve their administrative performance in schools. This could be realized by setting a clear vision for the school, adequate job analysis and work plan, professional meeting with staff and effective instructional supervision. No wonder, why the Ministry of Education in Ekiti State directed all the principals to prepare 5-year development plan for their various schools. However, it seems that some school principals in Ekiti State lack vision, there appears to be inadequate job analysis and work plan with poor instructional supervision which culminated into poor curriculum delivery in schools and consequently poor academic performance by the students. Hence, the need by the government to compel all the school principals of both senior and junior secondary schools in Ekiti State to write a test conducted sometimes ago in August 2011 and face an oral interview before appointing the qualified ones into 
position of principal ship. The set standard for appointment was based on minimum of $52 \%$ as average score in the three types of tests conducted for the principals. Hence, any principal who scored below $52 \%$ was not appointed as a school principal, but rather they were made to become vice- principals mainly because emphasis is now shifted on maintaining quality assurance in secondary school system.

A critical look at the students' academic performance over the years shows that the expected learning outcome has not been achieved because the percentage level of performance is relatively low. This implies that much work is being expected to be performed by principals and teachers in order to improve the level of students' academic performance in secondary schools in Ekiti State. It is against this background that the government decided to reposition secondary school administration guarantee quality assurance in the delivery of educational programme in Ekiti State purposely to reclaim the lost glory in the education sector.

\section{Concept of Secondary School Administration}

Secondary school administration could be defined as the systematic arrangement of human and materials resources including activities designed to achieve educational goals at the secondary level of education. Oyewole (2006) noted that the principal is the chief executive officer in the Nigerian secondary school system. He is a teacher and administrator. Hence, the principal is regarded as the most important functionary in the secondary school system. The principal performs a good number of administrative functions in their efforts to achieve goals and objectives for which the schools are primarily meant to achieve. It is pertinent to say that the goal of a school administrator is to ensure success in his school with respect to laid down objectives (Ekiti State Universal Basic Education Board, 2012). In the light of this, the success of the school administrator depends on his effectiveness in steering the ship of the school to be able to facilitate success.

Sheppared and Dibbion (2010) observed that the effectiveness of a school administrator is a function of his/her ability to identify certain basic components of his/her assignment. He/She will thus be able to use his/her expertise to apply these elements for the smooth running of the school. To this end, secondary school administration could only function effectively through the application of the following elements: planning, organizing, coordinating, commanding, controlling and decision making. All these carefully combined will distinguish a good administrator from a bad one.

\subsection{Planning}

Planning determines which direction an organization should go and the approaches to adopt for the administrator to get desired result. Thus, it is the first of all managerial functions. Planning could be a short, medium or long term depending on what is designed to be achieved (Ayodele, 2002). A school administrator must take into cognizance that planning involves determining objectives, examining the environment and forecasting changes, and developing plans to ensure the achievement of objectives in a given environment.

\subsection{Organising}

More importantly, the school administrator's organizing ability determines the ways and strategies through which the planned goals can be achieved. It becomes highly imperative for a school principal to be aware that he is dealing with people of high potentials which must be properly harnessed to achieve desired school goals and objectives. Hence, a school administrator should be more knowledgeable about human resources in this regard.

\subsection{Commanding}

Commanding is also vital in effective school administration. Ibukun (1997) asserted that authority is the right to issue instructions and that power is the right to make oneself obeyed. The school principal has the power to command and give instructions that will guide both teachers and students under his leadership. In achieving this, the school administrator needs to be more tactful, understanding and flexible in approaches adopted to deal with human resources in secondary school setting.

\subsection{Coordination}

This involves the ability and capability of the school administrator to put together human and material resources at his disposal and use them for better achievement of the school objectives (Omotayo, 2010). The success of a school administrator rests solely on his ability to coordinate efforts in the school system.

\subsection{Controlling}

Controlling deals with organizational objectives with plans; and making necessary adjustments and corrections where there are deviations between plans and objectives. Ajayi and Ayodele (2001) observed that control is the managerial skills that ensure effective acquisition and use of the organization's resources to achieve stated objectives. 


\subsection{Decision Making}

Decision making is the actual selection among various alternatives in taking any course of action. It is pertinent to note that some school principals find it difficult to take decision, while most leaders in particular wish to shy away from their responsibility. This is because, the process is very rigorous and demanding (Ekiti State Universal Basic Education Board, 2012). Therefore, a school principal must be ready to face the challenges of undergoing the process of decision making which involves deliberating, calculating or reflecting over an issue either consciously or unconsciously before taking a particular action.

Taking into cognizance the elements of school administration briefly discussed above, it becomes highly essential for a good school administrator to stand distinctively among colleagues in the school system. He or she must possess certain characteristics that will distinguish him/her from the followers (teachers and students). Hence, principal ship is second only to teaching in its impact on effective school administration towards ensuring good quality in the areas of teachers' job performance and students' academic performance. Thus, principals' administrative skills and strategies are the actions, behaviours and functions found through research and professional experience to have positive impact on quality assurance in schools (Lydiah \& Nasongo, 2009).

It is therefore important that the principal should see himself as a leader, a thinker and a decision maker. To this end, principals with good administrative strategies will employ team work strategy to facilitate teachers' job effectiveness and better students' academic performance as all stakeholders have a key role to play in ensuring qualitative education in our secondary school system especially in Ekiti State.

\section{Concept of Quality Assurance in Schools}

Quality in Nigerian educational system especially at the secondary education level is a multidimensional concept which should embrace all its functions and activities; administration; teaching and academic programmes, research and scholarship, staffing, students, buildings, facilities, equipment, services to the community and the academic environment (Rammon-Yusuf, 2003). Okebukola (2004) as cited in Omoregie (2008) saw quality assurance in schools as a process of continuous improvement in the quality of teaching and learning activities which will be achieved via pathways of employing mechanisms both internal and external.

Oyewole (2009) observed that adequate attention must be given to the teaching delivery of the academic staff (teachers) in order to maintain standards and quality assurance in schools. In a review of the debate whether or not standards are actually falling, Afenikhe (1988) opined that there is a consensus of opinions that the quality of education must be maintained at a high level. Also, Ijeoma (1997) remarked that the achievement of excellence is highly dependent on the right caliber of teaching staff and the maintenance of conducive working and learning environment. In this direction, the principals of secondary schools have a significant role to play in maintaining high quality of education in their various schools because they serve as catalyst and motivator that could help to achieve the set goals and objectives of secondary education at the national level. Hence, the idea of repositioning secondary school administration for quality assurance in Ekiti State could make a lot of impact in improving the standard of education which is perceived to have declined especially in Ekiti State, Nigeria.

\section{Strategies for Repositioning Secondary School Administration in Ekiti State}

There are various measures put in place to reposition the school administration for the purpose of quality assurance in the educational system at the secondary education level in Ekiti State. These are briefly discussed as follows:

\subsection{Merging of Senior and Junior Secondary Schools}

In Ekiti State as at August 2011, there were 183 public secondary schools made of Junior and Senior sections under the administration of different school principals. Hence, as at that time, there were three hundred and sixty six (366) secondary schools principals in Ekiti State. In order to facilitate the achievement of this new development, both junior and senior secondary schools were merged together to form a single school under the administration of a single principal though retaining the identity of junior and senior school sections in line with the educational policy in Nigeria. With the merger of schools, the number of school principals reduced by fifty percent.

\subsection{Conduct of Performance-Based Tests for School Principals}

All the junior schools principals and senior schools principals were subjected to rigorous examinations to determine their level of competency. The intention of Ekiti State Ministry of Education in collaboration with the Teaching Service Commission was to appoint school principals and vice principals based on level of performance in the standardized tests. This was strictly to determine the managerial skills and abilities of school 
principals before appointing the qualified ones based on merit. The performance based tests were conducted in three different levels. First, the principals were asked to prepare a 5- Year Development Plan for their various schools which was based on $40 \%$. Second, all the principals were given written tests which covered areas like essay, management and current affairs which attracted $30 \%$. Third, was the oral interview conducted for all the principals to determine their suitability for appointment and this was also based on $30 \%$. The cumulative total score gave $100 \%$. The set standard for appointment was based on $52 \%$ and above. Hence, any principal who scored 52\% and above was appointed while those who scored below this mark were made to become vice principals. Hence, the appointment of secondary school principals by the Teaching Service Commission in Ekiti State was strictly on merit.

\subsection{Appointment of New Tutor Generals}

The appointment of three new tutor generals from the three senatorial districts in Ekiti State was another measure put in place to reposition school administration. All the principals who scored $62 \%$ and above were short listed for interview. From the analysis of the principals' performance in the earlier tests, only sixteen principals scored $62 \%$ and above out of all the principals that participated in the performance-based tests. The qualified principals were made to undergo oral interview conducted by educational experts who were invited from the universities before short listing six candidates for appointment. The state government there after screened the six candidates very thoroughly before appointing three of them, one from each senatorial district in Ekiti State. This was done to ensure genuine transformation of the educational system especially at the secondary school level without much bias, undue interference and political influence.

With this process, it could be observed that every appointment into sensitive administrative positions in secondary schools in Ekiti State was based on excellent performance of the candidates in the selection exercise. This is quite laudable as those who are now in charge of secondary school administration in Ekiti State could be perceived to be highly competent in managerial skills.

\section{Challenges of Repositioning Secondary School Administration in Ekiti State}

There are various challenges of repositioning the secondary school administration in Ekiti State. It took the boldness and determination of the Ministry of Education and Teaching Service Commission before this could be achievable because of public criticisms and stiff opposition that various interest groups developed against this new dispensation. The challenges that face the new arrangement are listed as follows:

a. Reduction in the number of schools principals by fifty percent there by making the space available for administrative positions to become few.

b. Appointment of school principals solely on good performance in aptitude tests not minding the steps or grade level of school principals before.

c. Low morale on the part of ex-principals now demoted to vice principals but salary made personal to them.

d. Inability to accept change easily as many vice principals became head of departments and some head of departments lost their positions.

e. Increase in the school population to be managed by a school principal as both the teachers and students of junior and senior secondary schools are now coming together as a single school.

f. Re-orientation and adjustment of teachers to this new development as any teacher could be assigned any class either at junior or senior levels or both.

g. Problem of funding and maintenance of school facilities.

h. Lack of cooperation between the school principals and their subordinates (ex-principals now vice principals or head of departments) as many became jealous and there by display low level of commitment to school programme.

\section{Prospects of Repositioning Secondary Schools Administration}

The prospects of repositioning secondary schools administration for quality assurance in Ekiti State are highlighted and briefly discussed as follows:

\subsection{High Competency of School Principals}

Presently, the secondary schools principals in Ekiti State could be perceived to be highly competent in school administration sequel to their level of performance in the selection process. There is no doubt that secondary schools administration has been geared towards quality assurance of the educational programme. It is pertinent 
to note that there are now 183 public schools principals in Ekiti State since the number has reduced by $50 \%$. The level of competency of the schools principals could be assured as many of the former senior secondary schools principals were selected based on their level of performance and years of experience while many of the former junior secondary schools principals were appointed as vice -principals, hence a formidable team is now administering the school system thereby supporting Argyris maturity-immaturity continuum.

\subsection{Removal of Dichotomy between Senior and Junior Secondary Schools}

This is another great achievement in repositioning secondary school administration for quality assurance in Ekiti State. Before, junior and senior secondary schools were very distinct as many of the principals in junior secondary schools completely changed the school uniform of their students based on personal interests. There are situations where restrictions were made to both the teachers and students of these schools. Hence, they cannot interact freely on the same school compound. This does not augur well for cordial relationship as they likely pursue different goals. With this new arrangement, all the teachers and students of junior and senior schools have now come together and working towards achieving a common goal. The students are now wearing the same school uniform and sharing the school facilities together as the school administration has now been centralized.

\subsection{Unity and Team Work among Teachers}

In an effort to promote quality assurance in schools, capable hands are now assigned to teach specific classes based on areas of specialization and needs. Some senior school teachers are now teaching junior classes while some brilliant teachers in junior schools have been assigned to teach senior classes. This has given room for more interaction among the teachers and developing the spirit of team work in promoting the quality of education in our secondary schools. No doubt, a lot of challenges have been placed on the teachers as they need to update their knowledge in their subject areas rather than recycling on a particular class. Many could now make some researches to meet up with the curriculum content and thereby becoming more proficient in skills acquisition and content delivery.

\subsection{Centralization of School Policies}

Many of the policies in the school system have become centralized under the close supervision by the Ministry of Education. There is now an approved unified levy that a principal could collect from any student. It does not vary from one school to another. There is now a unified promotion examination for all the students in SSII in public secondary schools across the state. They now write the same examination in all subject areas and their scripts are exchanged for marking just like public examinations like WAEC or NECO. To be promoted to SSIII, a student must have minimum of five credits including English Language and Mathematics. Any student who fails to meet this requirement is not qualified to be promoted. Hence, emphasis is now on quality of students to be presented for external examinations. This has made many students to become more serious with their studies and the teachers ready to teach very well in the class as the performance of both the teachers and students are now judged by other examiners from other schools. This is a laudable effort to promote quality assurance in secondary education in Ekiti State. No doubt, if this could be sustained, there will be improved performance of students in public examinations especially in WAEC and NECO conducted Senior Secondary School Examinations (SSCE).

\subsection{Improved School Infrastructures and Facilities}

The state of infrastructures in some public secondary schools in Ekiti State has been improved. There is now massive renovation of school buildings which took care of about 100 public secondary schools out of 183 public secondary schools in the first phase of the renovation exercise. The essence of this is to create a conducive teaching and learning environment in our secondary schools. Some students were given laptops to enhance their studies in schools while all the teachers were to be supplied a laptop each though they are to pay on installment. However, adequate attention must be placed on training both the teachers and students on the use of these facilities if the desired result should be fully realized.

\subsection{Effective Supervision of Schools}

There is now persistent internal and external supervisions of schools. The principals, vice principals and head of department are now monitoring the activities of the teachers to enhance better job performance. No school principal wants to betray the confidence placed on him or her as every principals intends to justify the criteria of the appointment. Hence, the level of commitment and job performance of both the principals and teachers could be perceived to be high. The tutor generals and other officials from Ministry of Education now visit schools 
regularly to monitor the activities and give advice and guidance in areas where necessary. This another measure put in place to promote the quality assurance of educational programme in Ekiti State.

\section{Conclusion}

The repositioning of secondary school administration for quality assurance in Ekiti State could be described as a right step in the right direction. The poor performance of students in public examinations has been a major concern to the government and other stake holders in the education sector. The poor state of infrastructures has been very alarming and the non-challant attitude of some school principals has consequently affected the quality of education in Ekiti State before. With the new development and major restructuring, performance and competency are now being emphasized as yardsticks for the appointment of any school principal. The present crops of school administrators are highly competent and determined to transform the secondary education in Ekiti State towards achieving the national goals and objectives of secondary education in Nigeria. No principal wants to be relieved of his or her position because of non-performance or gross misconduct. Therefore every hand is now on deck to ensure qualitative education in all the public secondary schools in the state. This is highly commendable and rewarding. Indeed, there is a new dawn towards revamping the lost glory of educational standards in Ekiti State and other states in the federation could emulate this positive step to improve the quality of education in Nigeria.

\section{Recommendations}

Based on the discussions above and the conclusion of this paper, the following recommendations were made:

1) The Teaching Service Commission in Ekiti State should always consider the level of performance, competency and years of experience in the appointment of secondary schools principals.

2) The government should continue to provide adequate infrastructures and facilities in the schools to create a conducive teaching and learning environment for both teachers and the students.

3) The Ministry of Education in collaboration with the Teaching Service Commission should organize regular training through conferences, seminars and workshops for the schools principals to enhance their performance.

4) The government should also increase the running grants released to public secondary schools for effective administration of the school system. The paucity of fund to carry out important administrative duties by the schools principals should be urgently addressed.

5) The schools principals should energize and motivate their vice principals (ex-principals) to perform through delegation of duties and creating in them a sense of belonging using team management.

6) The tutor generals should provide necessary mentorship to all the principals and maintain the constant supervision of school programmes for quality assurance of educational system.

\section{References}

Afenikhe, O. A. (1988). What standards. In Oriafo, S. O. (Ed.), Standards in the 6-3-3-4 system in Nigeria. Institute of Education, University of Benin, Benin City.

Ajayi, I. A., \& Ayodele, J. B. (2001). Fundamentals of educational management. Ado- Ekiti: Greenline Publishers.

Ayodele, J. B. (2002). Management challenges of primary education in Nigeria. Journal of contemporary issues in education, 1(1), 85-94.

Ekiti State Universal Basic Education Board. (2012). Teacher professional development training: Towards effective school administration. Ekiti State University, Ado-Ekiti.

Ibukun, W. O. (1997). Educational management: Theory and practice. Ado-Ekiti: Bamgboye Press.

Ijeoma, M. E. (1997). Maintaining excellence in higher education under conditions of economic depression. Studies in educational planning and administration, 1(1), 41-47.

Lydiah, L. M., \& Nasongo, J. W. (2009). Role of head teacher in academic achievement in secondary schools in Vihiga District, Kenya. Journal of social sciences, 1(3), 84-92.

Omoregie, N. (2008). Quality assurance in Nigerian university education and credentialing. Education winter.

Omotayo, O. T. (2010). Ghana, Gambia workshop on development of material for West African head teachers. Common wealth of learning with Memorial University, Canada. 
Oyewole, B. K. (2006). Secondary schools administration and maintaining quality in Nigerian educational system. Journal of research in vocational and technical education, 3(1), 30-36.

Oyewole, B. K. (2009). Instructional supervisory techniques and quality assurance in Nigeria universities. Knowledge review: A multidisciplinary journal, 19(5), 14-20.

Rammon Yusuf, S. B. (2003). The role of the national universities commission in quality assurance in Nigerian universities. NUC Monographic Series, 1(9), 1-23.

Sheppared, S., \& Dibbion, D. (2010). School culture and climate. Memorial University, Canada.

Wekessa, G. W. (1993). The impacts of head teachers instructional leadership on student academic achievement in Kenya. Unpublished Ph.D Dissertation, Teachers College, Columbia, Columbia University.

\section{Copyrights}

Copyright for this article is retained by the author(s), with first publication rights granted to the journal.

This is an open-access article distributed under the terms and conditions of the Creative Commons Attribution license (http://creativecommons.org/licenses/by/3.0/). 